\title{
A New-fangled Corona virus coupled with Human Respiratory and AI in COVID-19 Discovery
}

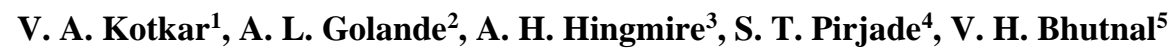 \\ 1,2,3,4,5 Assistant Professor, JSPM's Rajarshi Shahu College of Engineering
}

Article History: Received: 10 November 2020; Revised: 12 January 2021; Accepted: 27 January 2021; Published online: 05 April 2021

\begin{abstract}
Recently a very strange time to fight with invisible enemy. The Corona virus ailment 2019 also known as COVID19 outburst, which emerged from Wuhan, the Hubei Province, China, had broaden to all the regions of China and 28 additional countries. Corona viruses are a group of viruses with non segmented, single stranded and positive-sense RNA genomes. Corona viruses is also popular to contaminate human hosts and effect respiratory disease like brutal SARS-CoV (Acute Respiratory Syndrome Corona virus) and MERS-CoV (Middle East Respiratory Syndrome Corona virus). In this paper we discussed on detail analysis of COVID-19 disease.
\end{abstract}

Keywords: Corona virus, COVID-19, Pandemic.

\section{Introduction}

The name Corona virus is derived from the Latin word corona, meaning "crown" or "halo" because the virus has "crown-like spikes on their surface". Corona viruses are a ancestors of viruses which start from the widespread cold to MERS corona virus, that is available in MERS (Middle East Respiratory Syndrome) corona virus and SARS (Severe Acute Respiratory Syndrome) corona virus. Corona viruses are mostly found to be circulated in animals but few of these corona viruses have the potential of transit from animals and humans and vice-versa. Corona viruses were primarily discovered among chicks in year 1930 when an finely tuned respiratory contamination of domestic chickens was exposed to be caused by Infectious Bronchitis Virus (IBV). Human corona viruses were discovered in the 1960s.

In today's era due to the emerging infectious disease there is a huge threat in public about these diseases, like SARS (Severe Acute Respiratory Syndrome) and Zika virus disease. In December 2019, SARS-CoV (Severe Acute Respiratory Syndrome $\beta$-Corona virus) was detected in Wuhan, China. It was initially named as 2019nCoV (2019-Novel Corona virus) on 12th January 2020 by World Health Organization (WHO) and later WHO officially named the disease as COVID-19(Corona virus Disease 2019). On 11th February 2020, according to the survey it has also been found that there is a close genetic relationship between SARS-CoV and SARS-CoV-2.

There are many species of virus found in Bats, which are also known as natural resource of viruses such as Nipah, Ebola, Rabies, Hendra and Marburg. $\alpha-\mathrm{CoV}(\mathrm{Alpha}-\mathrm{CoV})$ and $\beta-\mathrm{CoV}$ (beta-CoV) are also been detected in bats in Asian and African countries and some parts of America. CoV's are single-stranded, optimistic sagacity RNA viruses with a comparatively large genome size 26 to $32 \mathrm{~kb}$. They are classified into four generations namely $\alpha-/ \beta-/ \gamma-/ \delta-\mathrm{CoV}$. From this $\alpha$ - and $\beta-\mathrm{CoV}$ are highly capable of infecting mammals, while $\gamma-$ and $\delta$-CoV primarily have a propensity to contaminate birds. The transmission of SARS-CoV-2 mainly takes place from one human being to another i.e. among family unit, relations and acquaintances that came into contact with patients.

\section{How Corona virus can be spread?}

There are three major symptoms how a Corona virus is spread:

1. The first major transmission of Corona virus is when a person is coughing and sneezing without covering his/her mouth/nose and spread the droplets in the air.

2. The second reason is when Handshaking or touching an infected person.

3. The third reason is when a person touches a plane or an entity which consist of droplets of disease and after the person touches his/her eyes, nose or mouth.

National Institutes of Health $(\mathrm{NIH})$ provides the different teams of public those who are at high risk due to COVID-19. In this people from age group of 60 and above, children's of age group 0-10 and pregnant ladies are there; also people who are underlying any medical conditions are also prone to such viruses.

\section{Is there a cure for corona virus?}

There is no specific treatment available till date, but doctors are using the existing drugs for viruses such as Ebola, malaria and HIV. Development of a vaccine is in progress many scientists are working on it, but it is 
unlikely to be available in next year.

Phenotype and Genotype of Covid-19

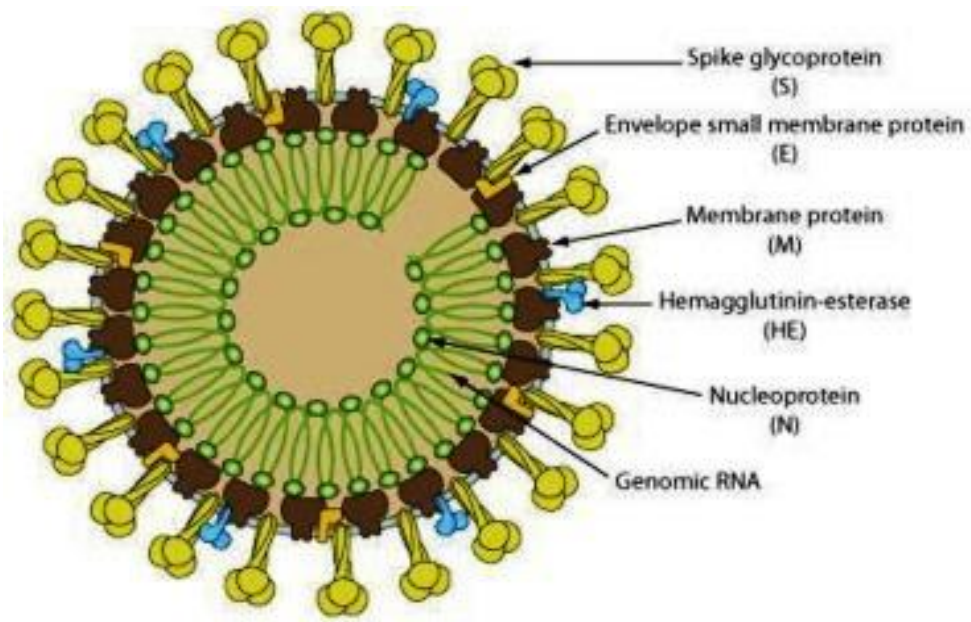

Figure 1. Schematic of a corona virus. (http://ruleof6ix.fieldofscience.com/2012/09/a-new-coronavirus-shouldyoucare.html)

Corona virus i.e. COVID19 is a sphere-shaped or pleo-morphic collected particles which consist of singlestranded (positive-sense) RNA linked by means of nucleoprotein inside capsid consisting of surrounding substance protein. The shape of the wrapper is club-shaped glycoprotein projections. Some of the corona viruses also contains a hem agglutinin-esterase protein (HE)[6] (Fig. 1).

Corona viruses owns the major genomes $(26.4 \mathrm{e} 31.7 \mathrm{~kb})$ out of all available RNA virus, with $\mathrm{G}$ p C stuffing changeable from $32 \%$ to $43 \%$. changeable figures of tiny ORFs are there stuck between the variety of sealed genes (envelope, membrane, ORF1a/b, spike, and nucleo capsid). The viral genome also has some typical features, counting a sole $\mathrm{N}$-terminal portion inside the spear protein. Genes for the most important structural proteins in each corona virus take place in the $50 \mathrm{e} 30$ classify as S, E, M, and N[7] (Fig. 2).

A distinctive $\mathrm{CoV}$ includes a smallest count of six ORFs in its genome. Apart from Gamma corona virus with the aim of lakes nsp1, the primary ORFs $(\mathrm{ORF} 1 \mathrm{a} / \mathrm{b})$, with reference to two-thirds from the entire genome measurement lengthwise, encode 16 nsps (nsp1-16). ORF1a and ORF1b hold a frame shift amongst that produce two polypeptides: ppla and pplab.

(A)

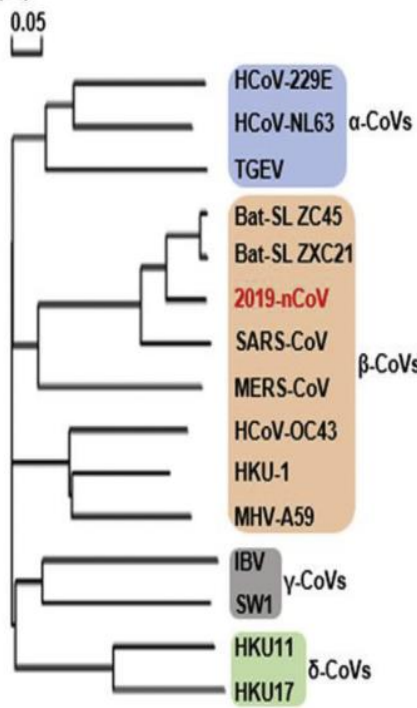

(B)

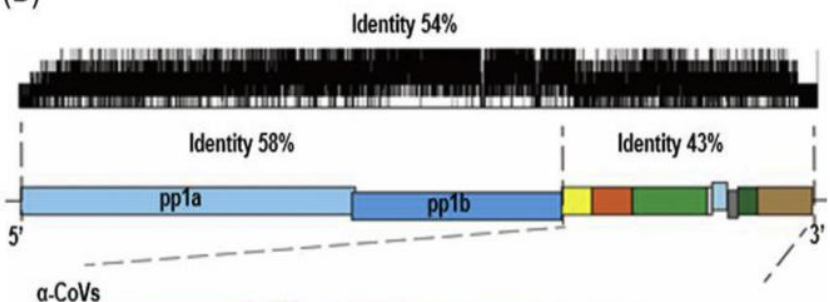

a-CoVs
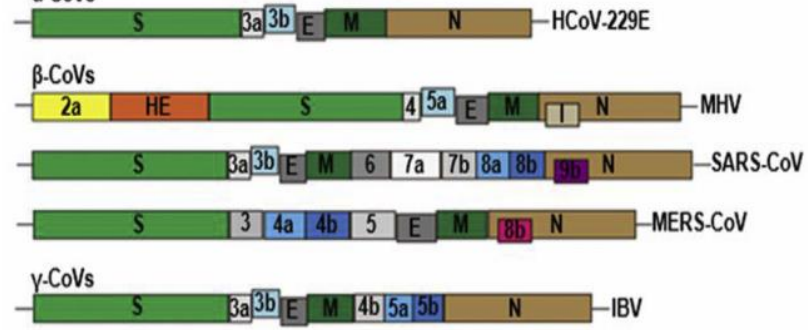

ס.CoVs

Figure 2. The genomic structure and phylo-genetic tree of corona-viruses. [1] 


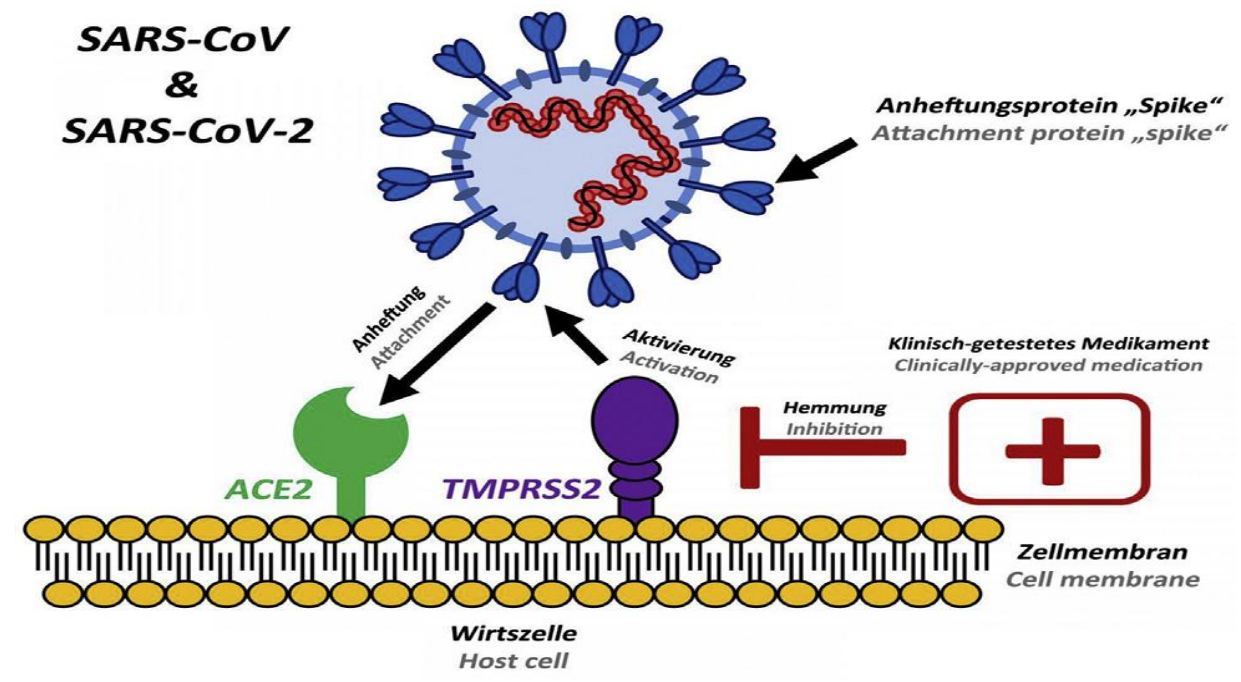

Figure 3. Protein "spike" of the novel corona-virus COVID19 and SARS-CoV make use of identical cellular connection aspect (ACE2) and cellular protease TMPRSS2 to activate themselves. [3]

Difference between SARS-COVID19, SARS-CoV, and MERS-CoV, these 50UTR, 30UTR are mixed up in inter and intra-molecular exchanges which are very significant from the functionally perspective for RNAeRNA exchanges and for fastening of viral and cellular proteins. [4] Pb1ab is the foremost ORF of the entire genome measurement lengthwise programming non-structural proteins by means of size of 29844bp (7096aa) for COVID-19, 29751bp (7073aa) in SARS-CoV and 30119bp (7078) MERS-CoV, correspondingly. Also when we are comparing the spike protein of all the corona viruses particularly for COVID-19 it is 1273aa, SARS-CoV it is 21493aa, and 1270aa for MERS-CoV. Hereditarily, COVID-19 was found not as much of same as of SARS-CoV (around 79\%) and MERS-CoV (around 50\%). The understanding of envelope protein(E), nucleocapsid protein $(\mathrm{N})$, and membrane protein (M) among these three corona viruses is different as shown in Fig. 3.[5]

\section{Literature Survey}

Fan $\mathrm{Wu}$ et. al. the study has been carried out on a model of bronchoalveolar lavage fluid out of the 41year old patient recognized novel RNA virus strain commencing the relations Coronaviridae, that is elected here 'WHHuman1' coronavirus. Phylogenetic examination of the whole viral genome (29,903 nucleotides) discovered that the virus was mainly strongly associated ( $89.1 \%$ nucleotide similarity) to a cluster of SARS-like corona viruses. This disease damage was nominated as WH-Human 1 coronavirus (WHCV). To conclude the evolutionary associations sandwiched between WHCV and beforehand recognized corona viruses, phylogenetic trees was predictable on the foundation of the nucleotide sequence of the whole-genome sequences, the non-structural protein genes ORF1a and ORF1b, and the chief structural proteins programmed by the S, E, M and N genes. For enhanced accepting the latent of WHCV to contaminate humans, the receptor-binding domain (RBD) of its spike protein was differentiated with others like SARS-CoVs and bat SARS-like CoVs. The RBD sequence of WHCV were further strongly correlated to that of SARS-CoVs.

Shrikrushna Subhash Unhale et. al. as we include witness the coming out of two zoonotic, exceedingly pathogenic HCoVs: severe acute respiratory set of symptoms corona virus (SARS-CoV) and Middle East respiratory set of symptoms corona virus (MERS-CoV). Reproduction of HCoV is synchronized by a variety of host factor and induces severe alteration in cellular organization and functioning. In this paper authors has reviewed all the information available related to corona virus including types, life cycle of virus, transmission, symptoms that can be observed, how it can be Diagnosed, available Treatment, and Prevention methods. Statistics on region wise count of cases and death count across all over the world and Indian region wise statistics is also present.

Yan-Rong Guo et. al. with the most recent investigation development of the epidemiology, pathogenesis, and medical distinctiveness of COVID19, and with the existing knowledge of SARS-CoV-2 the authors summarized the information as above: Initially, the rising pneumonia, COVID19, caused by SARS-CoV-2, exhibit muscular contamination but a smaller amount virulence, compared to SARS and MERS, in requisites of morbidity and mortality. Initiating from pool of bats and unidentified transitional hosts, SARS-CoV-2 binds to ACE2 with towering resemblance as a virus receptor to contaminate humans. Secondly, the vulnerable inhabitants involves the old and citizens with convinced original medicinal circumstances, which require added concentration and 
care. Thirdly, the underneath treatment, collectively with strong antiviral drugs, such as remdesivir, chloroquine, or lopinavir/ritonavir, were performed with explicit results on treating COVID19 patients.

Lifang Li et. al. [10] during this pandemic situation public use societal medium to get hold of and switch over different types of information at a notable and exceptional level. As the on-spot data is important for the civic and establishment to answer to the outbreak, it became extremely vital to recognize such situational data and to comprehend how it is life form propagated on societal medium. This paper tries to plug this opening by harnessing Weibo data tool and NLP techniques and distinguished the COVID-19-related data in seven different types of situational data like, concern and recommendation, fatalities and harm contributions of money, commodities, or services, people absent, found, or seen.

Wen-Hua Kong et. al. job has been carried out to re-analyse 640 throat swabs composed from patients in Wuhan with influenza-like-illness from 6 October 2019 to 21 January 2020 and bring into being that 9 of the 640 throat swabs were positive for SARS-CoV-2 RNA by quantitative PCR, signifying the public show of SARSCoV2 in Wuhan in the beginning January 2020. The discovery of SARS CoV- 2 cases amongst confined patients with ILI suggests that the public spread was recognized in Wuhan in the early hours in January. Relating to the current outbreaks episode on the Diamond Princess Cruise ship and Daequ, South Korea, the author suggested the intensification the pathogen observation of ILI cases in all cities facing the hazard of SARS-CoV-2 the public spread.

Michael Dub'e et. al. the Graph Evolution Tool (GET) was build to produce individual get in touch with network on behalf of who can contaminate whom surrounded by a community. GET is prolonged upon to reproduce communities which comprise 512 individuals in up to eight districts, Originally infecting one person in one region and dispersion all the way through a society.

Said Nadeem as this deadly disease is incredibly new and incredibly less methodical matter is obtainable on the subject, a variety of paid journals and companies are contributing by giving free resources in print about the Coronavirus. In this paper, all the articles about Coronavirus that are unreservedly provided by a range of journals and companies in the region of the planet are discussed. This examination is also unbolt to update so if any free starting place can be further added or modernized at this point.

\section{Analysis of Corona Virus Diseases}

Below Table 1. shows that analysis of coronavirus diseases.

Table 1. Analysis of Coronavirus Diseases

\begin{tabular}{|c|c|c|c|c|c|c|c|}
\hline $\begin{array}{l}\text { Sr. } \\
\text { No. }\end{array}$ & Year & $\begin{array}{l}\text { Disease } \\
\text { Name }\end{array}$ & Details & Symptoms & $\begin{array}{l}\text { No. of } \\
\text { affected } \\
\text { People }\end{array}$ & $\begin{array}{l}\text { No. of } \\
\text { people } \\
\text { death }\end{array}$ & Transmission \\
\hline 1 & 1965 & $\begin{array}{l}\text { HCoV- } \\
\text { OC43- } \\
\text { beta } \\
\text { coronaviru } \\
\text { s }\end{array}$ & $\begin{array}{l}\text { Human coronavirus } \\
\text { OC43 is a part of the } \\
\text { type Betacoronavirus } 1 \\
\text { which infects humans } \\
\text { and farm animals. }\end{array}$ & $\begin{array}{l}\text { common } \\
\underline{\text { cold }}\end{array}$ & $\begin{array}{l}\text { Millions } \\
\text { every year }\end{array}$ & - & $\begin{array}{l}\text { lock contact } \\
\text { through } \\
\text { contaminated } \\
\text { humans or } \\
\text { touching a } \\
\text { plane that carry } \\
\text { the virus. }\end{array}$ \\
\hline 2 & 1966 & $\begin{array}{l}\text { HCoV- } \\
229 \mathrm{E}- \\
\text { alpha } \\
\text { coronaviru } \\
\text { s }\end{array}$ & $\begin{array}{l}\text { Human coronavirus } \\
229 \mathrm{E} \text { is a type of } \\
\text { coronavirus which } \\
\text { infects humans and } \\
\text { bats. }\end{array}$ & $\begin{array}{l}\text { Starting from } \\
\text { the common } \\
\text { cold to high- } \\
\text { morbidity } \\
\text { outcomes } \\
\text { such as } \\
\text { pneumonia } \\
\text { and } \\
\text { bronchiolitis. }\end{array}$ & $\begin{array}{l}\text { Millions } \\
\text { every year }\end{array}$ & - & $\begin{array}{l}\text { lock contact } \\
\text { through } \\
\text { contaminated } \\
\text { humans or } \\
\text { touching a } \\
\text { plane that carry } \\
\text { the virus. }\end{array}$ \\
\hline 3 & 2002 & $\begin{array}{l}\text { SARS- } \\
\mathrm{CoV}\end{array}$ & $\begin{array}{l}\text { SARS-CoV (Severe } \\
\text { Acute Respiratory } \\
\text { Syndrome), } \\
\text { established to transmit } \\
\text { amongst civet cats to }\end{array}$ & $\begin{array}{l}\text { Fever, } \\
\text { headchae } \\
\text { and muscle } \\
\text { pain, } \\
\text { followed in }\end{array}$ & 8,098 & 774 & $\begin{array}{l}\text { Supposed to } \\
\text { have spread } \\
\text { from bats, } \\
\text { which } \\
\text { contaminated } \\
\end{array}$ \\
\hline
\end{tabular}




\begin{tabular}{|c|c|c|c|c|c|c|c|}
\hline & & & humans. & $\begin{array}{l}2-14 \text { days by } \\
\text { the onset of } \\
\text { respiratory } \\
\text { symptoms } \\
\text { mostly } \\
\text { cough, } \\
\text { dyspnea, and } \\
\text { pneumonia. }\end{array}$ & & & $\begin{array}{l}\text { civets. } \\
\text { Transmitted } \\
\text { mostly among } \\
\text { humans } \\
\text { through close } \\
\text { contact. }\end{array}$ \\
\hline 4 & 2004 & $\begin{array}{l}\text { HCoV- } \\
\text { NL63 - } \\
\text { alpha } \\
\text { coronaviru } \\
\text { s }\end{array}$ & $\begin{array}{l}\text { Human corona-virus } \\
\text { NL63 is a species of } \\
\text { corona-virus which was } \\
\text { recognized in late } 2004 \\
\text { in a seven-month-old } \\
\text { child with bronchiolitis } \\
\text { in the Netherlands. }\end{array}$ & $\begin{array}{l}\text { hoarseness, } \\
\text { bronchitis, } \\
\text { fever, cough, } \\
\text { rhinitis, sore } \\
\text { throat, } \\
\text { bronchiolitis, } \\
\text { pneumonia, } \\
\text { and croup }\end{array}$ & $\begin{array}{l}\text { Millions } \\
\text { each year. }\end{array}$ & - & $\begin{array}{l}\text { Close contact } \\
\text { with } \\
\text { contaminated } \\
\text { humans or } \\
\text { touching a } \\
\text { plane that carry } \\
\text { the virus. }\end{array}$ \\
\hline 5 & 2005 & $\begin{array}{l}\text { HCoV- } \\
\text { HKU1- } \\
\text { beta } \\
\text { coronaviru } \\
\text { s }\end{array}$ & $\begin{array}{l}\text { Human coronavirus } \\
\text { HKU1 is a species of } \\
\text { coronavirus } \\
\text { originated which } \\
\text { contaminated mice. }\end{array}$ & & $\begin{array}{l}\text { Millions } \\
\text { every year. }\end{array}$ & - & $\begin{array}{l}\text { Close contact } \\
\text { with } \\
\text { contaminated } \\
\text { humans or } \\
\text { touching a } \\
\text { plane that carry } \\
\text { the virus. }\end{array}$ \\
\hline 6 & 2012 & $\begin{array}{l}\text { MERS- } \\
\mathrm{CoV}\end{array}$ & $\begin{array}{l}\text { Middle East } \\
\text { Respiratory Syndrome } \\
\text { (MERS- CoV) of } 2012 \\
\text { was begin to broadcast } \\
\text { from dromedary camels } \\
\text { to humans. }\end{array}$ & $\begin{array}{l}\text { fever, cough } \\
\text { and tininess } \\
\text { of breath. } \\
\text { Some also } \\
\text { had diarrhea } \\
\text { and nausea. }\end{array}$ & 2,521 & 866 & $\begin{array}{l}\text { Often from } \\
\text { touching } \\
\text { contaminated } \\
\text { camels or } \\
\text { overriding } \\
\text { their milk or } \\
\text { meat partial } \\
\text { spread between } \\
\text { humans } \\
\text { throughout } \\
\text { close contact. }\end{array}$ \\
\hline 7 & 2019 & $\begin{array}{l}\text { SARS- } \\
\text { CoV-2 }\end{array}$ & $\begin{array}{l}\text { Initially, scientists } \\
\text { thinking the virus may } \\
\text { have urbanized in bats, } \\
\text { and afterwards } \\
\text { pangolins. However, } \\
\text { genomic comparisons } \\
\text { propose that the SARS- } \\
\text { Cov-2 virus is the } \\
\text { effect of a } \\
\text { recombination among } \\
\text { two unlike viruses, } \\
\text { meaning the accurate } \\
\text { origin of the virus is } \\
\text { still unclear. }\end{array}$ & $\begin{array}{l}\text { cough, fever, } \\
\text { difficulty } \\
\text { breathing, } \\
\text { pneumonia } \\
\text { in both lungs }\end{array}$ & $\begin{array}{l}\text { more than } \\
1,290,000 \\
\text { till } \\
\text { April } 7,2020\end{array}$ & $\begin{array}{l}76,000 \\
\text { Till } \\
\text { April } \\
7,2020\end{array}$ & $\begin{array}{l}\text { Likely from } \\
\text { touching or } \\
\text { eating an } \\
\text { infected, as yet } \\
\text { unknown } \\
\text { animal. } \\
\text { Human-to- } \\
\text { human } \\
\text { transmission } \\
\text { occurs through } \\
\text { close contact. }\end{array}$ \\
\hline
\end{tabular}

\section{AI in covid-19 detection}

As the COVID-19 epidemic carry on to boost transversely the sphere, Industries and researchers are finding many ways to utilize AI as a technique of solving the challenge of the virus. At this point presently a quantity of the projects by means of AI to that deal with the corona-virus epidemic.

AI system were considered to be amongst the initial to notice so as to the corona-virus outburst, reverse while it was immobile imperfect to a small area of the Chinese city of Wuhan, possibly will turn out to be a full- 
on international epidemic. It's consideration that AI-driven Health-Map, which is associated with the Boston Children's Hospital, Collected the improving cluster of mysterious pneumonia belongings soon previous to human being researchers, even though it only rank the outbreak's importance as medium.

An Assistant professor from the department of psychology, Stanford University named Johannes Eichstaedt, had been investigating Twitter posts to guess how COVID-19, and updates are brought to the way how we live our lives, is upsetting our psychological fitness. By means of AI-driven text examination, Eichstaedt queried over two million tweets hash tagged with COVID-related stipulations for the period of February and March, and pooled it with further datasets on applicable factors counting the no. of cases, deaths, demographics and other, to light the virus effects on mental healthiness.

Canadian startup Darwin AI has urbanized a neural network which could monitor X-rays for signs of COVID-19 contagion. When using swabs of patients is default for testing for coronavirus, analyzing chest Xrays might tender a choice to hospitals that does not have an adequate amount of workforce or testing kits to course all of the patients rapidly.

A machine-learning community owned by Google named Kaggle is scenery to no. of COVID19 associated challenge to the members of family, together with fore-casting the no. of cases and fatalities by city as a means of guessing accurately why a variety of spaces are beat inferior than others. Deep Mind, the AI appendage of Google's parent corporation Alphabet, is accessing data on genomes to forecast organisms protein organization, potentially flaking glow on which drugs could work adjacent to COVID19.

No. of research projects are making use of AI to be familiar with drugs which were urbanized so as to struggle further disease although which could now be re-purposed to acquire on corona-virus. By understanding the molecular set of connections of lively drugs with AI, companies want to recognize which ones may disturb the pattern in COVID19 works.

\section{Experimental Results}

We have analyzed Covid19 dataset of India which is available on Kaggle. The dataset which is used here is collected over period of 30 January 2020 to 16 may 2020.

\begin{tabular}{|c|c|c|c|c|c|c|}
\hline In [63]: & \multicolumn{6}{|c|}{$\begin{array}{l}d f=d f . \text { sort_values(by=' confirmed', ascending=False) } \\
\text { print(df) }\end{array}$} \\
\hline & \multicolumn{3}{|c|}{ statename state code } & \multirow{2}{*}{$\begin{array}{r}\text { district } \\
\text { Mumbai }\end{array}$} & \multirow{2}{*}{$\begin{array}{r}\text { confirmed } \\
18555\end{array}$} & \multirow{2}{*}{$\begin{array}{r}\text { active } \\
14599\end{array}$} \\
\hline & 339 & Maharashtra & MH & & & \\
\hline & 153 & Delhi & $D L$ & Unknown & 8545 & 4491 \\
\hline & 161 & Gujarat & GJ & Ahmedabad & 8144 & 5106 \\
\hline & 597 & Tamil Nadu & TN & Chennai & 6279 & 5025 \\
\hline & 356 & Maharashtra & MH & Thane & 3834 & 3021 \\
\hline & 349 & Maharashtra & MH & Pune & 3647 & 2007 \\
\hline & 408 & Madhya Pradesh & MP & Indore & 2378 & 1179 \\
\hline & 537 & Rajasthan & RJ & Jaipur & 1552 & 585 \\
\hline & 739 & West Bengal & $W B$ & Kolkata & 1265 & 667 \\
\hline & 189 & Gujarat & GJ & Surat & 1049 & 313 \\
\hline & 542 & Rajasthan & RJ & Jodhpur & 993 & 255 \\
\hline & 395 & Madhya Pradesh & MP & Bhopal & 954 & 394 \\
\hline & 562 & Telangana & TG & Hyderabad & 944 & 616 \\
\hline & 326 & Maharashtra & MH & Aurangabad & 873 & 588 \\
\hline & 344 & Maharashtra & MH & Nashik & 835 & 535 \\
\hline & 640 & Uttar Pradesh & UP & Agra & 806 & 278 \\
\hline
\end{tabular}

Figure 4. It shows the district wise confirm cases in India in descending order. Where we can see that, Mumbai, capital of Maharashtra is having highest number of covid cases 
In [62]: df.head()

Out[62]:

statename statecode district confirmed active deceased recovered

153 Dehi DL Unknown $8545 \quad 4491 \quad 128 \quad 3926$

339 Maharashtra MH Mumbai $1855514599690 \quad 3260$

101 Gujarat GJ Ahmedabad $8144 \quad 5100 \quad 493 \quad 2545$

349 Maharashtra MH Pune $3647 \quad 2007 \quad 188 \quad 1452$

597 Tamil Nadu TN Chennal $6279 \quad 5025 \quad 52 \quad 1202$

Figure 5. It shows the count of recovered cases of COVID 19 is highest in Delhi

\begin{tabular}{|c|c|c|c|c|c|c|c|c|c|c|}
\hline \multirow{2}{*}{$\begin{array}{l}\text { In [102]: } \\
\text { Out[102]: }\end{array}$} & \multicolumn{10}{|c|}{ df. sort_values (by= 'DeathRate' , ascending=False) } \\
\hline & & statename & state code & district & confirme: & ed activ & ive decease & sed recovere & & DeathRate \\
\hline & 573 & Telangana & TG & Mancherial & & 1 & 0 & 1 & 0 & 100.000000 \\
\hline & 687 & Uttar Pradesh & UP & Lallipur & & 1 & 0 & 1 & 0 & 100.000000 \\
\hline & 579 & Telangana & TG & Narayanpet & & 1 & 0 & 1 & 0 & 100.000000 \\
\hline & 56 & Assam & AS & Hallakandi & & 1 & 0 & 1 & 0 & 100.000000 \\
\hline & 546 & Rajasthan & RJ & Other State & & 7 & 3 & 4 & 0 & 57.142857 \\
\hline & 201 & Himachal Pradesh & HP & Mandi & & 2 & 0 & 1 & 1 & 50.000000 \\
\hline & 390 & Madhya Pradesh & MP & Ashoknagar & & 2 & 1 & 1 & 0 & 50.000000 \\
\hline & 357 & Maharashtra & MH & Warcha & & 2 & 1 & 1 & 0 & 50.000000 \\
\hline & 690 & Uttar Pradesh & UP & Mahoba & & 3 & 0 & 1 & 2 & 33.333333 \\
\hline & 346 & Maharashtra & MH & Other State & & 41 & 31 & 10 & 0 & 24.390244 \\
\hline & 548 & Rajasthan & RJ & Pratapgarh & & 5 & 1 & 1 & 3 & 20.000000 \\
\hline & 398 & Madhya Pradesh & MP & Chhindwara & & 5 & 1 & 1 & 3 & 20.000000 \\
\hline & 543 & Rajasthan & RJ & Karauli & & 10 & 5 & 2 & 3 & 20.000000 \\
\hline & 741 & West Bengal & WB & Murshidabad & & 5 & 4 & 1 & 0 & 20.000000 \\
\hline
\end{tabular}

Figure 6. State wise Death Rate in India: Here states like Telangana, Uttar Pradesh and others are having highest death rate, as the number of confirmed cases are only one.

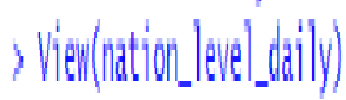

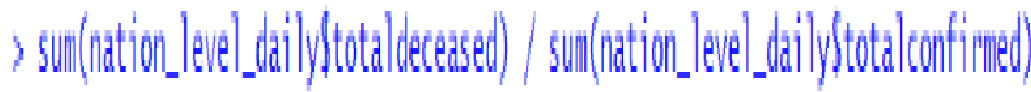

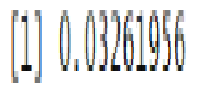

Figure 7. Death rate in India :3.2. 


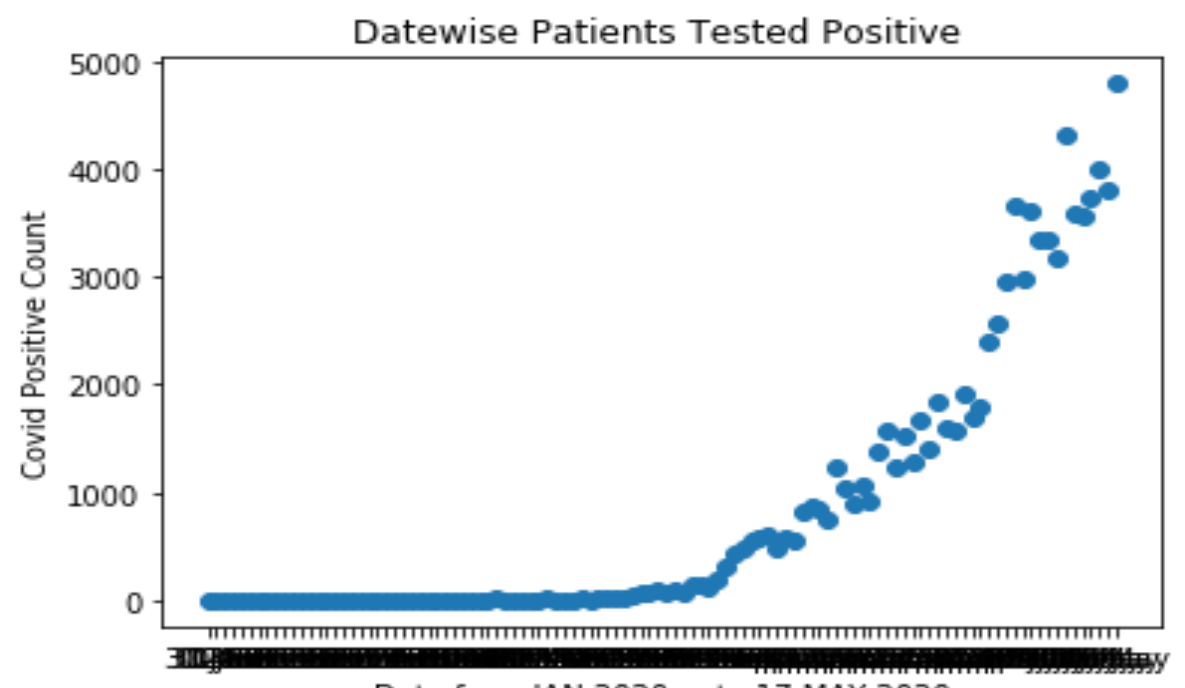

Date from JAN 2020 upto 17 MAY 2020

Figure 8. Date wise Tested Positive cases of COVID 19 in India

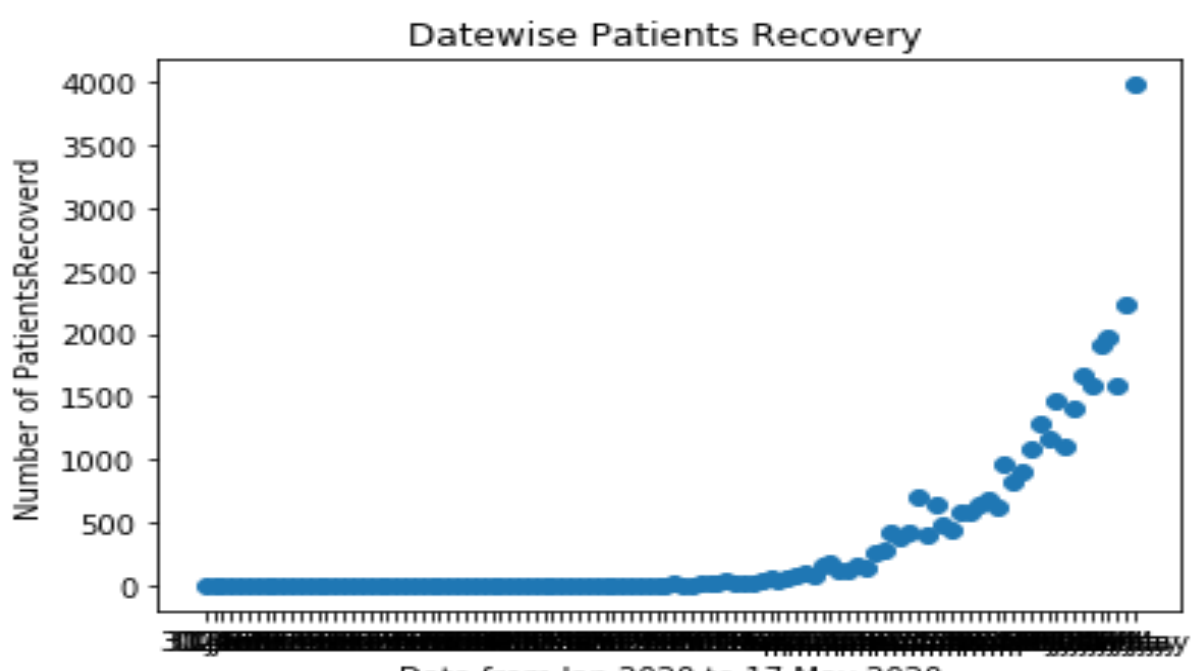

Date from Jan 2020 to 17 May 2020

Figure 9. Day wise patients recovery in India

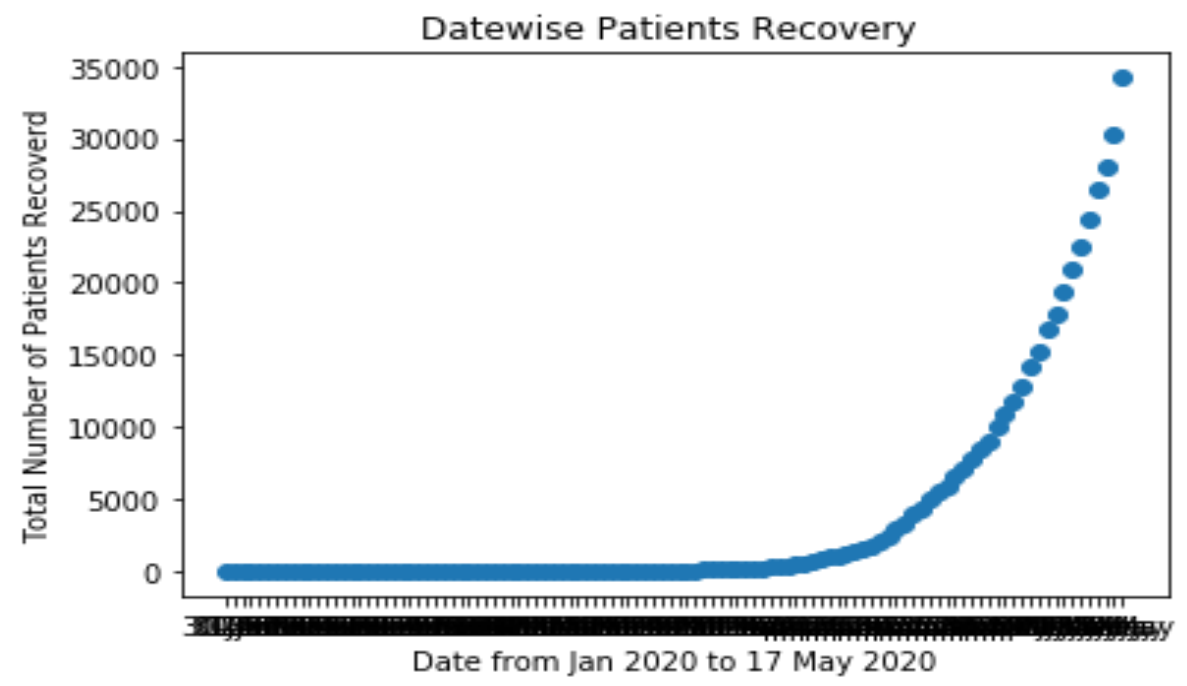

Figure 10. Day wise total number of patients recovered in India. 
Here it shows that the lockdown declared in the country worked well to control the spread of Covid-19 and the result also shows that the recovery of patient in India is also good.

\section{Conclusion}

In this paper we did the detailed analysis of corona virus i.e. COVID-19 with their symptoms and how to take cure. Addressing the different challenges of the viruses by using Artificial Intelligence as a method. AI system were found to be amongst the initial to notice with the aim of corona virus outburst. In this paper we analyzed COVID-19 dataset of India which is available on Kaggle. In India lockdown has been declared to control the spread of COVID-19 and the outcome of this shows that the recovery rate of patients is good.

\section{References}

1. Chen Y, Liu Q, Guo D. Emerging coronaviruses: genome structure, replication, and pathogenesis. J Med Virol 2020

2. Lu R, Zhao X, Li J, Niu P, Yang B, Wu H, et al. Genomic characterization and epidemiology of 2019 novel coronavirus: implications for virus origins and receptor binding. Lancet 2020; 395(10224)

3. Hoffmann M, Kleine-Weber H, Schroeder S, Krüger N, Herrler T,Erichsen S, et al. SARS-CoV-2 cell entry depends on ACE2 and TMPRSS2 and is blocked by a clinically proven protease inhibitor. Cell 2020. https://doi.org/10.1016/j.cell.2020.02.052.

4. Yang D, Leibowitz JL. The structure and functions of coronavirus genomic 30 and 50 ends. Virus Res 2015;206

5. R, Zhao X, Li J, Niu P, Yang B, Wu H, et al. Genomic characterisation and epidemiology of 2019 novel coronavirus: implications for virus origins and receptor binding. Lancet 2020; 395(10224)

6. de Haan CAM, Kuo L, Masters PS, Vennema H, Rottier PJM. Coronavirus particle assembly: primary structure requirements of the membrane protein. J Virol 1998;72(8):6838e50.

7. Woo PCY, Huang Y, Lau SKP, Yuen K-Y. Coronavirus genomics and bioinformatics analysis. Viruses 2010;2(8):1804e20.

8. Said Nadeem, "Coronavirus COVID-19: Available Free Literature Provided by Various Companies, Journals and Organizations around the World", Journal of ongoing Chemical Research, Vol. 5, Issue 1, pp. 7-13, 2020.

9. Shrikrushna Subhash Unhale, Quazi Bilal Ansar, Shubham Sanap, Suraj Thakhre, Shreya Wadatkar, Rohit Bairagi, Prof. Suraj Sagrule and Prof. Dr. K. R. Biyani, "A REVIEW ON CORONA VIRUS (COVID-19)", World Journal of Pharmaceutical and Life Sciences, Vol. 6, Issue 4, pp. 109-115, 2020.

10. Lifang Li, Qingpeng Zhang, Xiao Wang, Jun Zhang, Tao Wang, Tian-Lu Gao, Wei Duan, Kelvin Kam-fai Tsoi, and Fei-Yue Wang, "Characterizing the Propagation of Situational Information in Social Media During COVID-19 Epidemic: A Case Study on Weibo", IEEE Transactions On Computational Social Systems, Vol. 7, No. 2, pp. 556-562, 2020.

11. Zhiwen $\mathrm{Hu}$, Zhongliang Yang, Qi Li2, An Zhang and Yongfeng Huang, "Infodemiological study on COVID-19 epidemic and COVID-19 infodemic", pp. 1-12, 2020.

12. Manohar Lal Choudhary, Veena Vipat, Sheetal Jadhav, Atanu Basu, Sarah Cherian3, Priya Abrahamand Varsha A. Potdar, "Development of in vitro transcribed RNA as positive control for laboratory diagnosis of SARS-CoV-2 in India”, Indian Journal of Medical Research 671-20, pp. 14, 2020.

13. Pragya D. Yadav et. al., "Detection of coronaviruses in Pteropus \& Rousettus species of bats from different States of India", Indian Journal of Medical Research 795-20, pp. 1-10, 2020.

14. Michael Dub'e, Sheridan Houghten and Daniel Ashlock, "Pandemic: A Graph Evolution Story", IEEE, pp. 1-8, 2019.

15. Wen-Hua Kong, Yao Li, Ming-Wei Peng, De-Guang Kong, Xiao-Bing Yang, Leyi Wang and ManQing Liu, "SARS-CoV-2 detection in patients with influenza-like illness", Nature Microbiology, pp. 1-8, 2020.

16. Fan $\mathrm{Wu}$ et. al., "A new coronavirus associated with human respiratory disease in China", Nature, Vol. 579, pp. 265-285, 2020.

17. Roman Wölfel et. al., "Virological assessment of hospitalized patients with COVID-2019", Nature, pp. 1-17, 2020.

18. Yan-Rong Guo et. al., "The origin, transmission and clinical therapies on coronavirus disease 2019 (COVID-19) outbreak - an update on the Status", Military Medical Research, pp. 1-10, 2020.

19. C.G. Raut et. al.," Isolation of a Novel Adenovirus from Rousettus leschenaultii Bats from India", 
Intervirology, pp. 1-4, 2012.

20. Pragya Yadav et. al., "Isolation of Tioman virus fromPteropus giganteus bat in North-East region of India”, Elsevier Infection, Genetics and Evolution, pp. 224-229, 2016.

21. Pragya D Yadav et. al., "Serosurvey of Malsoor virus among Rousettus leschenaulti bat \& human population residing nearby Robber's cave, Mahabaleshwar, Maharashtra, India”, Indian Journal of Medical Research 301-16, pp. 545-547, 2017.

22. Pragya D Yadav et. al., "Circulation of Nipah virus in Pteropus giganteus bats in northeast region of India, 2015”, Indian Journal of Medical Research 1488-16, pp. 318-320, 2018. 